\title{
Estado, democracia e institucionalização das lutas sociais nas práticas educativas do MST: um estudo de caso da escola itinerante
}

\author{
Moacir Fernando Viegas* \\ Charles Luiz Policena Luciano*
}

\section{Resumo}

No artigo analisamos as características e contradiçóes das práticas educativas desenvolvidas nos acampamentos do Movimento dos Trabalhadores Rurais Sem Terra (MST) tendo como referência a Escola Itinerante. Enfocamos especialmente o problema da democracia e da institucionalização das lutas sociais, questáo central com a qual se debatem os movimentos sociais na atualidade. Apoiamos a pesquisa no materialismo histórico e dialético e, nesse artigo, na crítica de Ellen Meiksins Wood à democracia representativa e às limitaçóes do conceito de "sociedade civil". Desenvolvemos o estudo em dois acampamentos do MST localizados no Rio Grande do Sul por meio de entrevistas semiestruturadas, observação participante e análise de documentos. Os resultados a que chegamos apontam que a institucionalizaçáo das práticas educativas do movimento, ao atenderem as formalidades do Estado, tendem à burocratização, distanciando-se das necessidades da classe trabalhadora.

Palavras-chave: Educação e democracia. Educação e luta de classes. Movimentos sociais.

* Doutor em Educação pela Universidade Federal do Rio Grande do Sul. Professor do PPGEdu da Universidade de Santa Cruz do Sul, RS.

** Mestre em Desenvolvimento Regional pela Universidade de Santa Cruz do Sul. Professor da rede estadual de educação pública no município de Rio Pardo, RS. 


\section{Introdução}

O objetivo principal desse artigo é analisar as características e contradiçóes das práticas educativas que se desenvolvem nos acampamentos do Movimento dos Trabalhadores Rurais Sem Terra (MST) tendo como referência a Escola Itinerante. Enfocamos especialmente o problema da democracia e da institucionalização das lutas sociais, questáo central com a qual se debatem os movimentos sociais na atualidade. $\mathrm{O}$ estudo enquadra-se no conjunto de investigaçóes sobre educação no MST classificadas por Souza (2007, p. 443) como "prática pedagógica no âmbito das relaçóes sociais que caracterizam o movimento social", na medida em que não se propóe a investigar a educação no âmbito restrito de uma prática pedagógica e, sim, no interior das relaçóes sociais que se realizam no acampamento, em suas relaçôes com o Estado, e que são próprias do movimento social MST.

Como metodologia, além de entrevistas semiestruturadas, utilizamos a observação participante que permitiu descrever as práticas sociais cotidianas vivenciadas nos acampamentos, onde, de forma intercalada, permanecemos em torno de três meses. O estudo foi realizado em dois acampamentos: o primeiro, chamado Unidos Venceremos, fica localizado no município de Arroio dos Ratos e possui cinco anos. O segundo, Jair Antônio da Costa, fica em Nova Hartz e trata-se de um acampamento "emergente", com apenas três meses. Ambos localizam-se no estado do Rio Grande do Sul.

Apoiamos a pesquisa no materialismo histórico e dialético e, nesse artigo, na crítica de Wood (2003) à democracia representativa e às limitaçóes do conceito de "sociedade civil" que apontam para uma prática social integrada às relaçóes sociais capitalistas.

Os resultados a que chegamos assinalam que a institucionalização das práticas educativas do movimento, ao atenderem as formalidades do Estado, tendem à burocratização, distanciando-se das necessidades da classe trabalhadora, passando a mediar os interesses do capital. $\mathrm{O}$ processo de institucionalizaçáo caminha pari passu com as melhorias infraestruturais e assistenciais, as quais, nos casos investigados, levam o movimento e suas práticas educativas a perder em dinamicidade, enfraquecendo a democracia direta.

Em nossa análise, a contradição principal em que está inserido o MST é a tentativa de conciliar a luta por direitos sociais universais, inseridos na 
sociedade civil e materializados, no caso de nossa investigação, na Escola Itinerante, com as lutas de classe que ocorrem nos acampamentos. O problema a enfrentar é que esses direitos sociais correspondem à democracia representativa em que o Estado se posiciona ativamente para garantir as relaçóes globais do livre mercado, enquanto que a emancipação humana se inviabiliza.

\section{Sociedade civil, democracia e Estado}

Entendemos a democracia, elemento central para pensar a educação, não como um objeto em si, mas como uma relação de poder que possibilita a realização de acordos políticos. As práticas sociais do MST, na atualidade, inserem-no num contexto de valorização das lutas por direitos sociais na esfera da sociedade civil. Essa situação é característica da democracia representativa em que os problemas sociais criados pelas políticas econômicas, como o desemprego, são transferidos para a sociedade civil, dissociados de suas raízes econômicas. Tal condição permite ao capital tornar-se mais concentrado e explorador, livre das pressôes sociais.

Wood (2003) critica a compreensão de que a emancipação poderia ocorrer por meio de lutas no campo denominado por ela de bens "extraeconômicos” (emancipação de gênero, igualdade racial, paz, saúde, ecologia), por vezes ligados à questão da identidade, quando se ignora as lutas de classe. Essa crítica baseia-se no fato de que, para os capitalistas, tanto faz as identidades que exploram. Para a autora, as identidades só têm força social emancipadora quando estão aliadas à luta de classes. O capitalismo é capaz de aproveitar toda opressão "extra-econômica" construída histórica e culturalmente em benefício próprio. E ainda que existam condiçôes de superação das desigualdades raciais ou da opressão de gênero, as relações estruturais de exploração permanecem intactas, pois as lutas pelos bens "extra-econômicos" são travadas na esfera da sociedade civil, muitas vezes contra o Estado, mas não contra as questóes essencialmente políticas da economia.

O MST, embora também lute pela conquista de direitos universais, como é o caso da educação materializada na Escola Itinerante, tenta romper com a formalidade das lutas na esfera da sociedade civil, exercendo açóes contra a política econômica liberal. Estas açóes fortalecem os fundamentos sociais básicos da democracia para os sem-terra: 
De fato, o senso de caráter e dignidade forjado ao longo de anos de luta do MST tem nutrido cidadáos mais conscientes e promovido uma maior participação pública em assuntos locais. Ao capacitarem as pessoas a usarem seus direitos políticos, o MST tem ajudado a integrar centenas de milhares de brasileiros pobres e historicamente marginalizados no processo democrático. (CARTER, 2006, p. 23).

Isso significa que o MST reconhece a necessidade de considerar as múltiplas formas de luta na "sociedade civil", como aquelas relacionadas com as discriminaçôes e as opressões que, aliás, não são originárias do capitalismo, mas são apropriadas e aperfeiçoadas para manter a contradição de classe.

Conforme Wood (2003), a democracia é tão utópica dentro do capitalismo quanto a existência do próprio socialismo. Isto significa que ela é impossível de desenvolver-se plenamente nas estruturas do capitalismo e para uma verdadeira democracia é necessário mudar as estruturas através de relaçóes e de processos sociais e culturais, só possíveis com práticas que exponham as contradiçóes que se desenvolvem no seio do capitalismo, nomeadamente as contradições de classe.

É nesse contexto que encontramos o MST, um movimento social que busca contrapor-se aos imperativos do capital por meio da luta de classes. Como afirma Casagrande (2002, p. 6) a respeito dos movimentos sociais:

$$
\begin{aligned}
& \text { [...] além da luta pela transformaçáo das condições } \\
& \text { sociais existentes mais imediatas, consideramos } \\
& \text { que os movimentos sociais também visam alcançar } \\
& \text { transformaçóes mais radicais (que vão à raiz do } \\
& \text { processo) no âmbito das relaçóes sociais de produçáo, } \\
& \text { lutando pela socializaçáo dos meios de produçáo } \\
& \text { e pela aboliçáo da propriedade privada que vigora } \\
& \text { sobre os mesmos. }
\end{aligned}
$$

$\mathrm{Na}$ atualidade poucos são os movimentos sociais, sindicatos ou partidos políticos que se apoiam na contradição entre capital e trabalho. O MST busca organizar a classe trabalhadora rural para constituir uma resistência contra o capitalismo, embora considere fundamental inserir em suas lutas direitos civis possíveis de serem conquistados no atual modo 
de produção. Assim, o MST tem sido "um participante importante no desenvolvimento dos direitos de cidadania no Brasil - em todas as três dimensões contemporâneas desta ideia: direitos civis, políticos e sociais" (CARTER, 2006, p. 23). Para entendermos essa prática do MST, que objetiva articular a luta de classes com a conquista de direitos na sociedade capitalista, é necessário explicitarmos o significado de "sociedade civil".

A categoria "sociedade civil" está presente nas principais teorias contemporâneas sobre a emancipação e se encontra repleta de ambiguidades. Atualmente, serve para identificar um espaço de liberdade fora do Estado, além de reduzir o sistema capitalista ao rol das muitas esferas complexas e diversas da sociedade moderna. É um espaço de autonomia, pluralismo e de iniciativas voluntárias garantidas pela democracia formal que se desenvolveu no ocidente com a característica especial de ter gerado uma separação entre o Estado e a sociedade, tornando a economia capitalista uma entre várias práticas e relaçóes sociais.

Essa categoria, além de reviver a preocupação liberal com a limitação e legitimação do Estado, traz consigo o reconhecimento da diferença e da diversidade que não pode ser negado. Conforme Wood (2003, p. 210), "esse abrigo conceitual, que a tudo cobre, desde os lares e as associaçóes voluntárias até o sistema econômico do capitalismo, confunde e disfarça tanto quanto revela". O uso abrangente do conceito pode tornar o capitalismo "invisível" quando coloca todas as relaçóes sociais e o conjunto de instituiçóes de produçáo capitalistas com o mesmo peso em relação às associaçóes de bairros ou de voluntários. Essa compreensão, que não reconhece o sistema capitalista como uma unidade totalizadora, serve para negar a luta de classes ao mesmo tempo em que o capitalismo desaparece conceitualmente. Desta maneira, as instituiçóes capitalistas globais podem interferir diretamente nas políticas sociais dos países a elas submetidas.

Não negamos a importância da democracia em favor das liberdades civis, seus princípios de legalidade e a proteção de uma esfera não estatal. Numa compreensão que privilegia a importância da "sociedade civil", no entanto, a autonomia individual tem sido destacada como a forma adequada para conquistar os direitos civis. Segundo esse entendimento, o capitalismo seria apenas mais uma relação social, especializada somente nas questóes econômicas globais. Por essas e outras os pressupostos teóricos da defesa da "sociedade civil" reforçam a hegemonia da classe dominante: 
Essa função hegemônica que a classe dirigente exerce na sociedade civil dá ao Estado a razáo de sua representação como universal e acima das classes sociais. Entretanto, quanto mais desfavoráveis às classes dirigentes forem os fatos, tanto mais deverão estas desenvolver seu aparato ideológico para conservar sua hegemonia no interior da sociedade civil. (CURY, 2000, p. 57).

Para Cury (2000, p. 55), o Estado "adquire especial importância e função com o novo papel que passa a assumir no contexto da divisão internacional do trabalho", na manutenção de um equilíbrio político que visa atender os interesses das classes dominadas. Isso ocorre pelo caráter ambíguo do próprio processo de acumulação que ele ajudou a construir, como uma forma de corrigir ou atenuar os desequilíbrios socioeconômicos resultantes do mercado. Nesse contexto, a educação assume papel preponderante, entrando como elemento de intermediação para manter as concepçóes liberais nas relaçóes entre o capital e a sociedade. A política de dominação depende dessa presença do Estado que redefine suas estratégias de forma ágil e eficaz, exercendo uma função reguladora e organizadora do processo de acumulaçáo mediante pacto político com a classe trabalhadora. Para isso, o Estado liberal e a "sociedade civil" se completam e se apoiam na tentativa de relaxar as tensóes entre democracia liberal e capitalismo.

Para Wood (2003), na formação econômica capitalista ocorre a desvalorização dos bens políticos, baseado na separação entre o político e o econômico, fundando-se, pela primeira vez, uma democracia apenas política, sem implicaçóes nos setores econômicos (privados). Ou seja, o capitalismo permite uma vida comunitária separada da organização da produção e da comercialização onde podem acontecer muitos eventos na vida política sem tocar fundamentalmente nos poderes de exploração.

É dentro dessa discussão que identificamos o MST como um movimento social de classe que enfrenta o desafio da institucionalização de direitos civis que estáo sob controle do Estado liberal. No entanto, essa perspectiva de luta pode levar o movimento a uma orientaçáo equivocada quanto às consequências das conquistas no âmbito da sociedade civil na medida em que tais conquistas tendem a ser submetidas à lógica do capital, perdendo o referencial de classe. Assim, no caso da nossa pesquisa, a luta do 
MST pelo direito à educação é analisada como um resultado contraditório do processo hegemônico da classe dominante "que permite à classe subalterna reivindicar seus objetivos mediante mecanismos estabelecidos pela burguesia" (CURY, 2000, p. 48).

\section{As lutas do MST como práticas educativas}

Nas açóes do MST os sem-terra participam de uma extraordinária prática educativa, experienciada na própria situação da luta de classes vivida no cotidiano, nas exaustivas reunióes periódicas nos acampamentos, nos encontros formais dos congressos e nas marchas e ocupaçóes, naquilo que Freire (1999, p. 43) chama de um "movimento dinâmico, dialético, entre o fazer e o pensar sobre o fazer”.

De acordo com as ideias de Dalmagro (2002), as práticas históricas, as concepçóes de mundo e as propostas dos sem-terra, quando colocadas em movimento através das lutas, se constituem em práticas educativas, $\mathrm{o}$ que revela a primeira característica das mesmas:

Compreendemos, assim, que o próprio MST é educador dos sem terra, que aprendem estando presentes e participando de sua história. [...] A educação do MST se constrói de forma participativa, atuante e não passiva do sujeito sem-terra. Isso significa dizer que este se educa (no MST) através de sua própria ação, lutando, convivendo, estudando, produzindo, organizando-se. O Movimento só pode se realizar como educador se o sem-terra participar, agir, se puser em movimento. É um aprendizado que pressupóe a ação do aprendiz. (DALMAGRO, 2002, p. 135-136).

A expressão "luta" é uma constante nas práticas dos sem-terra, desde as mais corriqueiras até as mais complexas. As necessidades básicas estão colocadas permanentemente no limite da sobrevivência, tornando cada ação uma luta contínua de superação material dentro do acampamento, luta essa que contém em si uma dimensão educativa: "isto é, a experiência de vida educa pelas condiçóes de vida, pelo estilo de vida, pelas necessidades a serem preenchidas e pelos problemas reais com que uma classe se defronta" (CURY, 
2000, p. 95). Assim, destacamos o papel desempenhado pelas práticas educativas que são desenvolvidas na informalidade das práticas sociais, constituindo-se como referência de luta para os objetivos do MST. Como afirma Vendramini (2000, p. 86), os acampamentos podem ser considerados:

[...] um espaço agregador e que possibilita uma vivência cotidiana marcada por dificuldades conjuntas, por enfrentamentos, pelo aprendizado de uns com os outros e com a própria situação, por assembleias e reunióes diárias - (que)] é capaz de, em pouco tempo, fazer com que as pessoas tomem consciência da importância da coletividade e da sua capacidade de mudança. ${ }^{1}$

Iremos apresentar como essas práticas educativas se caracterizam nos acampamentos objetos de nossa investigação e que contradições apresentam quando formalizadas nas instituiçôes do MST, como a Escola Itinerante.

\section{As práticas educativas do MST e a institucionalização da Escola Itinerante}

Por não aceitar as condições que as relaçóes de produção impóem à maioria das pessoas, em que os "trabalhadores estão sujeitos tanto ao poder do capital quanto aos imperativos da competição e da maximização dos lucros" (WOOD, 2001, p. 173), o MST, conforme nosso entendimento, faz um contra movimento ao sistema capitalista. Esse movimento é sustentado pelas práticas educativas responsáveis pela formação política do sujeito Sem Terra. Logo, ao pensar no sem-terra como uma identidade de classe, pensase nas práticas educativas da Escola Itinerante; os pais partem para suas ocupaçóes com o sentimento de participar da construção da escola dos seus filhos. Pais e filhos vão se transformando na medida em que transformam a educação numa mistura entre culturas, lutas, utopias e pedagogias. Uma mãe que tem dois filhos no acampamento Unidos Venceremos afirma, por exemplo, que:

Quando entrei no acampamento achava muito difícil alguém que não estudou pra ser professora dar aula para os meus filhos. Sem falar da escola que não tinha 
nada, só algumas cadeiras e mesas. Mas participando das reuniōes fui percebendo que as aulas ensinam diferente de como eles estudavam lá fora, e que eles estavam aprendendo coisas que serviam pra vida deles. Hoje, acho que não trocaria esta escola por outra. É uma pena que depois vão ter que estudar em outra escola quando acabarem a $5^{3}$ série. Aqui nós podemos fazer nossas tarefas e ficar tranquilos, porque aqui todos cuidam de todos.

Decorridos dois anos da aprovação pelo Conselho Estadual de Educação do Rio Grande do Sul, a Escola Itinerante foi reconhecida oficialmente em 19 de novembro de 1996 com o nome de "Experiência Pedagógica”. Esse reconhecimento oficial teve como Escola-Base a Escola Estadual de Ensino Fundamental Nova Sociedade que se localiza no assentamento Itapuí, no município de Nova Santa Rita, e é responsável pelo aparato jurídico. Essa escola dá o suporte organizativo e institucional às Escolas Itinerantes de todos os acampamentos do estado.

A Escola Itinerante prevê organização em etapas que se caracterizam pela flexibilização e integração e que correspondem ao Ensino Fundamental do $1^{\circ}$ ao $5^{\circ}$ ano. Em linhas gerais, os conteúdos são construídos no decorrer das aulas, servindo-se dos acontecimentos produzidos historicamente, problematizados a partir das experiências de luta.

Segundo os integrantes do Setor de Educação, a organização curricular de cada etapa não é responsabilidade apenas dos educadores, mas também de pais e filhos. O currículo escolar é discutido antes e durante o processo educativo, o que possibilita a apreensão e a sistematização de conhecimentos conforme o processo de cada educando. E quando o educando constrói as referências de aprendizagem correspondentes a uma etapa pode passar para outra em qualquer época do ano letivo mediante avaliação realizada pelos educadores.

Como é uma proposta pedagógica específica e diferenciada, não necessita seguir as normas do calendário escolar da Lei de Diretrizes e Bases da Educação Nacional (BRASIL, 1996) que prevê 200 dias letivos, assim como o calendário oficial, que geralmente vai de março a dezembro. Conforme dirigentes do MST, a frequência e o horário são fixados com base no compromisso assumido entre educadores, educandos, comunidade 
do acampamento, Secretaria de Educação e MST. Ademais, os sem-terra entendem que a prática pedagógica na escola deve ser permanente, sendo o período de férias necessário, porém relativo.

Desse modo, no decorrer das mobilizações maiores do acampamento as aulas não cessam. $\mathrm{O}$ fato histórico contextualizado no exato momento em que acontece é mais educativo do que qualquer outro método, ficando o descanso das atividades escolares para outros momentos. Como afirma Cury (2000, p. 95), "a própria experiência de vida de uma classe é um momento pedagógico de intensa significação, e que dá uma certa ordem às açóes vividas".

Quanto à avaliação dos educandos, conforme o Setor de Educação, ela ocorre de forma global, participativa, continuada e atenta ao conhecimento construído pelo educando, pois diariamente ele é observado para verificar o que aprendeu em cada etapa. Para um lider intermediário ligado ao setor de educação, "avaliar significa compreender os momentos pedagógicos", com o objetivo não apenas de verificar o conhecimento de cada integrante, mas também de garantir que esse conhecimento seja resultado de uma relação e de um ambiente coletivo e democrático.

Do ponto de vista dos sem-terra, a pedagogia presente nas práticas não deveria ver mudadas apenas os seus pressupostos teóricos tradicionais, mas também a posição dos educadores e educandos e a maneira geral de ser da escola. Esta, no caso do MST, teve que se orientar, perceber e relacionar os acontecimentos históricos para inserir-se no tempo e no espaço em que se movimenta, além de trabalhar a gestão democrática, a auto-organização e a capacidade de decisão dos educandos. Como afirmou um indivíduo que foi educador da Escola Itinerante num encontro estadual em São Leopoldo, RS, em 2006:

Nós não impomos nada, tudo é discutido com a turma. Isso permite superar os conteúdos clássicos. Também faz a gente aprender com eles, porque eles já trazem suas experiências e mais aquilo que sua família já falou em casa. Aí, devagar, nós podemos introduzir novos conhecimentos. $\mathrm{Na}$ aula a gente ensina e aprende. 
A escola também é um lugar de reflexão sobre os valores desenvolvidos pela classe dominante e incorporados pela classe dominada, como o individualismo. Essa reflexão, apoiada pela experiência de vida, apresenta a possibilidade de elaboração e recriação das condiçóes materiais de existência. Conforme um líder, "é na escola que começa a reeducação dos valores entre as pessoas que são forjadas nas lutas, como valor de companheirismo e solidariedade".

Segundo um integrante entrevistado, a escola foi pensada como um agente revolucionário. As açóes do movimento, no seu conjunto, necessitam dessa prática educativa, pois tais açóes, desde as mais simples, como construir um barraco, até as mais complexas, como a elaboração de estratégias de ocupação, que dependem de vários procedimentos para a sua realização, são transformadas em conhecimentos a partir de reflexóes teóricas nas classes da Escola Itinerante. Assim, o objetivo é que na Escola Itinerante as práticas do MST se convertam em conhecimentos, onde "o próprio discurso teórico, necessário à reflexão crítica, tem de ser de tal modo concreto que quase se confunda com a prática” (FREIRE, 1999, p. 44). Para isso, a escola busca problematizar os acontecimentos da vida dos trabalhadores rurais.

A Escola Itinerante torna-se, então, uma ferramenta que alimenta seus educandos com concepçóes de vida contrárias aos valores e à cultura capitalistas por meio de uma pedagogia própria que visa compreender a realidade na medida em que tenta transformá-la, constituindo-se, assim, em base estruturante para as açóes do MST.

Como afirma Souza (2007, p. 447),

A educação do campo tem sido caracterizada como um novo paradigma, que valoriza o trabalho no campo e os sujeitos trabalhadores, suas particularidades, contradiçóes e cultura como práxis, em contraponto ao paradigma da educação rural, vinculado aos interesses do agronegócio, do capitalismo agrário e, consequentemente, ao fortalecimento das políticas de esvaziamento do campo.

\section{As práticas educativas nos acampamentos analisados}

O acampamento Unidos Venceremos fica localizado no município de Arroio dos Ratos, às margens da BR 290, distante 60km de Porto Alegre. 
Sua ocupação ocorreu em 2001, com aproximadamente 500 famílias. No período da pesquisa havia 150 famílias, as quais variavam, quanto ao tempo de acampamento, entre alguns meses e o máximo de quatro anos.

Se compararmos as condições de vida dos sem-terra no acampamento Encruzilhada Natalino ${ }^{2}$ com o Unidos Venceremos - no que diz respeito às políticas públicas de seguridade alimentar, educação, entre outras - houve, no último acampamento, avanços substanciais decorrentes de crescentes conquistas de direitos sociais, ocorridas principalmente no primeiro governo Lula. Esse acampamento conquistou infraestrutura suficiente para manter os sem-terra organizados, sem depender única e exclusivamente de suas mobilizaçóes coletivas para o alcance de questóes básicas, como, por exemplo, alimentos: "nós estamos numa vida muito boa. Pensa bem, no nordeste, os companheiros não têm água, luz, lenha e outras coisas que temos aqui e ficam cinco ou seis anos acampados [...]. A comida aqui é um luxo comparado com antes [...] e ainda a polícia batia em nós", como afirmou um acampado durante uma roda de chimarrão.

No entanto, apesar da melhoria das condiçóes de vida, que facilitam o ingresso e permanência de novos integrantes, existe uma contradição em termos de movimento. As lutas parecem se limitar às condiçóes de sobrevivência dentro do acampamento, o que tende a levá-lo a perder gradualmente a motivação material que impulsiona a luta contra o capital. Nesse acampamento nos deparamos com uma realidade bastante diferente daquilo que propóe a educação do MST, pois a escola estava funcionando de acordo com o calendário escolar tradicional. Quando iniciamos a pesquisa no mês de janeiro de 2006 ela tinha cessado suas atividades escolares, com a promessa dos educadores de que em seguida as mesmas recomeçariam, pois dependiam de uma reunião com o Setor de Educação Estadual.

O outro acampamento, Jair Antônio da Costa, fica localizado a $3 \mathrm{~km} \mathrm{da}$ cidade de Nova Hartz e possui aproximadamente 120 famílias. Não conta com barracos abandonados, como o Unidos Venceremos. Nesse acampamento, embora de forma improvisada, a Escola Itinerante estava funcionando quando da realizaçáo da pesquisa. Pelo fato de ser um acampamento "emergente" apresenta uma estrutura escolar em construção, sem salas de aula ou material escolar. Seus educadores estavam em fase de experiência, pois nunca realizaram tarefas de alfabetização antes de ingressarem no movimento. 
A estrutura geral do acampamento Jair Antônio da Costa corresponde à mesma do Encruzilhada Natalino, onde os barracos, que são formas improvisadas de moradia, possuem poucos utensílios domésticos, o que facilita a mobilização dos sem-terra. Nas situaçóes em que o acampamento apresenta barracos com estrutura similar a uma casa tradicional, com mobílias que oferecem condiçóes de conforto além do mínimo necessário, como geladeira e televisão, estamos diante de um acampamento que pode ter diminuída sua capacidade de luta, pois fica difícil deslocar-se para uma ação "com todas essas tralhas", ${ }^{3}$ como afirmou um acampado do Unidos Venceremos, reclamando da falta de mobilização.

Esse é o caso do acampamento Unidos Venceremos.

Desse modo, encontramos um acampamento "emergente" que, de forma improvisada, desenvolve suas práticas escolares com relativa autonomia, e outro mais antigo, que mesmo com uma estrutura mais apropriada, aguarda decisóes de outras instâncias para poder iniciar as atividades escolares.

A maior estruturação do acampamento Unidos Venceremos parece contribuir para a diminuição de sua dinamicidade. Nele o Setor de Educação é visto pelos demais e por ele próprio como capaz de auto-organização, tornando-se independente da organização geral que encontra muitas dificuldades para articular as necessidades do MST às práticas educativas. Tal situação foi reconhecida por um dirigente, que afirmou: "demos preferência aos outros setores e acabamos deixando de lado o setor da educação, pela sua autossuficiência”.

A escola torna-se igualmente independente da organização, podendo tomar suas próprias decisões. As prestações de contas não se dão diretamente à direção do acampamento, mas aos responsáveis pela educação do MST, em âmbito estadual, que possuem relações formais com o Estado. Cria-se assim um canal paralelo de práticas que permitem ao Setor de Educação, no acampamento, uma isenção de responsabilidades com relação às instâncias internas que somente são acionadas quando os problemas se popularizam entre os integrantes do acampamento.

Enquanto isso, no Jair Antônio da Costa, a Escola Itinerante segue os mesmos passos das primeiras escolas que no início funcionavam debaixo das árvores e depois passaram para barracóes de lona preta. Segundo uma 
educadora entrevistada, as crianças sentam no chão ou em pequenos bancos de madeira, com um material didático improvisado, até a conquista de um espaço pedagógico mais adequado, sem que com isso a aprendizagem deixe de ocorrer.

Como percebemos, as práticas educativas apresentam coerência com a proposta revolucionária do MST no acampamento que mantém sua dinamicidade e seu caráter de provisoriedade, caso do Jair Antônio da Costa, mas não no Unidos Venceremos, o qual, com uma infraestrutura melhor, apresenta certa acomodação de suas lutas.

\section{A Escola Itinerante e o Estado: institucionalização e movimento}

Como afirmamos, a forma predominante de compreensão do conceito de "sociedade civil" não contribui para uma prática social em que a classe dominada possa superar a contradição entre capital e trabalho, pois ignora as lutas travadas nas estruturas que sustentam a dominação material e cultural da classe dominante. No caso do MST, as conquistas dos direitos sociais alocados na "sociedade civil", como é o caso da institucionalização da Escola Itinerante, trazem riscos aos interesses dos sem-terra. Trata-se de direitos que são resultados das pressóes do movimento sobre o Estado. No entanto, o Estado concede o direito à educação e, ao mesmo tempo, impóe normas que regulam esse direito segundo seus interesses: "isto é, a manutenção da representação do Estado (universal) em contradição com seu conteúdo (classista) o fará buscar, na sociedade civil, os recursos para essa mesma manutenção" (CURY, 2000, p. 57).

O reconhecimento da Escola Itinerante possibilitou ao MST superar os problemas em relação à infraestrutura e, também, os advindos da pressão dos pais que desejavam uma escola institucionalizada que garantisse o certificado de conclusão de estudos dos filhos. Porém, a institucionalização da escola criou uma relação de dependência do Estado, da forma como a classe capitalista deseja para a manutenção da sua hegemonia: "de fato, a oficialização e a consequente regulamentação do saber em nossa sociedade o torna mais normatizado em relação aos interesses dominantes, através de agências formais" (CURY, 2000, p. 106). 
A institucionalização das práticas educativas na Escola Itinerante, no caso do acampamento Jair Antônio da Costa, caracteriza-se como uma conquista democrática e um instrumento de luta na formação política do sujeito sem-terra, nos moldes dos primeiros acampamentos. Esse mesmo caráter, embora provisório, transforma em práticas sistemáticas aquilo que surge espontaneamente entre os sem-terra. Em relação a essa escola podemos afirmar, com Cury (2000, p. 95), que instituiçôes como essas:

[...] ao darem uma certa forma ao espontâneo, elas ao mesmo tempo em que conformam, refinam, ao mesmo tempo em que reproduzem também transformam. Além da vivência que a tal formação conduz, a presença e o contato com esta forma que organiza, desde que assumidas sob nova perspectiva, permitem sua superação no próprio campo (ou melhor, a partir do) em que essa institucionalização se dá.

No Unidos Venceremos as práticas educativas da Escola Itinerante apresentam outras características. Conforme o coordenador do Setor de Educação do acampamento, "o governo estadual não repassou a ajuda de custo e o material didático" e como alternativa foi acionado o Setor de Educação Estadual para decidir quando recomeçariam as aulas. Esse setor percebe que o atraso do repasse das verbas é uma forma encontrada pelo Estado para dificultar as práticas educativas na escola. No entanto, a ação daí decorrente foi a discussão de formas de acessar os recursos, entendidos como fundamentais para colocar a escola em funcionamento.

A educação no MST, ao se qualificar na busca de direitos, como a conquista da Escola Itinerante, pode ficar dependente do Estado, reforçando as características da democracia representativa. Como consequência, a escola torna-se burocrática, o que dificulta sua capacidade de mobilização e a do próprio MST. A prática educativa entrega-se à conformidade e ao consentimento dos responsáveis, engessando-se como instrumento transformador ao cumprir as leis institucionais. Como diz Cury (2000, p. 119):

A burocracia pedagógica quer assegurar que cada um cumpra seu dever e, para tanto, impóem-se regras coercitivas que expressariam o interesse geral. Da parte 
do sujeito, ela quer que esse se conforme às regras que lhe são impostas. A medida da conformidade é a medida dos resultados que provam a própria conformidade.

Essa condição que envolve as práticas educativas do Unidos Venceremos está presente também nos estudos feitos por Vendramini (2000). A autora analisou os acontecimentos que se deram nas escolas de assentamento após a conquista da terra, encontrando indicativos de um processo de acomodaçáo da comunidade escolar em relação à participação. Ela chama atenção para o fato de "instituiçóes educativas ou de espaços ainda não institucionalizados terem sido criados pela iniciativa das comunidades, mas não terem uma participação efetiva destas após sua organização" (VENDRAMINI, 2000, p. 178). Uma vez burocratizada a escola, as lutas do MST não se transformam em práticas educativas na Escola Itinerante. Ademais, de acordo com Vendramini (idem), com o passar do tempo, parece que as escolas e a realização dos objetivos foram deixados apenas para os professores, separando-se da organização política mais geral do acampamento.

Tal situação vivida no acampamento Unidos Venceremos parece antecipar o que ocorre em casos investigados quando da conquista da terra, em que os sem-terra conformam-se aos direitos sociais conquistados, deixando de lado o caráter de luta presente em tempos anteriores. Nascimento (2005, p. 5) afirma que essa situação resulta de uma "cidadanização almejada". Afirma o autor que:

Outra curiosidade em relaçáo à conquista da terra revela-se nas formas de organização dos assentamentos. No acampamento o lema é a coletividade, todas as açôes são realizadas em conjunto, mas, com a conquista da terra, todos passam a agir individualmente em suas parcelas, assumindo o que Abramovay (1990) diz a respeito da assumência dos paradigmas do capitalismo agrário. Esta não ação coletiva leva a sérios problemas qualquer Assentamento (NASCIMENTO, 2005, p. 6).

Apesar do legítimo direito à educação dos trabalhadores do campo como algo necessário ao desenvolvimento de uma democracia participativa, a 
institucionalização da Escola Itinerante no acampamento Unidos Venceremos parece contribuir para uma existência menos dinâmica. As práticas educativas preocupam-se por demais com os processos burocráticos, administrativos, pedagógicos e curriculares a que o Estado submete a escola.

Já no acampamento Jair Antônio da Costa a Escola Itinerante desenvolve práticas educativas preocupadas com as necessidades dos sem-terra, com uma crítica às normas estaduais. Para os educadores, o período de aula não obedece ao calendário oficial e tão pouco suas práticas estão limitadas pelas verbas públicas. Como afirma uma educadora do acampamento Jair Antônio da Costa, "se não vier dinheiro para o material das crianças, como já aconteceu, nós pegamos dinheiro de outro lugar ou fazemos uma vaquinha”.

Entendemos que no Unidos Venceremos a institucionalização da Escola Itinerante configura um dos elementos que mantêm imobilizado o acampamento em termos de lutas de classes. Diferentemente do Jair Antônio da Costa, onde os educadores consideram as práticas educativas como mais importantes do que a institucionalização da escola: "dessa maneira, não é tanto uma instituição que está em jogo, mas o caráter processual que ela historicamente assume, por vezes modificada no seu projeto inicial" (CURY, 2000, p. 101).

\section{Considerações finais}

Não negamos a importância dos direitos civis conquistados pelo MST, mas, no caso da educação, a pesquisa que realizamos mostra que se deve ter cuidado quando assume o caráter institucional, porque a Escola Itinerante dos acampamentos que diminuem sua provisoriedade, no caso dessa e de outras pesquisas, tende a deixar de ser um instrumento transformador no momento em que começa a atender as formalidades do Estado. Os direitos, quando não são vistos de forma crítica, contribuem para a continuação da estrutura e da cultura capitalistas, combatidas quando a escola é livre das formalidades do Estado.

O acampamento Jair Antônio da Costa, que mantém sua provisoriedade, tanto em seus aspectos estruturais quanto nas práticas educativas, ganha em dinamicidade. Desta forma, as práticas educativas conseguem atender às necessidades dos sem-terra porque a mobilização do MST dá à escola 
condiçôes de colocar em prática suas estruturas revolucionárias. No acampamento mais antigo, onde as mobilizaçóes náo acontecem com tanta intensidade, as práticas educativas correm o risco de perder sua capacidade de reflexão sobre a realidade.

A exposição das estruturas do MST ao capital proporcionada, no caso, pela institucionalização da escola parece ser uma das portas que o Estado deseja para coagir o movimento, já que o MST procura fechar todos os espaços que possam oferecer interferências hegemônicas. Para isso, o Estado concede o direito à institucionalização e aos poucos vai introduzindo elementos burocráticos e evitando a democratização do ensino até a educação reproduzir as relaçóes de produção. O direito à educação, que poderia ser uma conquista dos trabalhadores do campo para a desocultaçáo da desigualdade, com contornos de uma democracia participativa, torna-se, no acampamento, um instrumento de coerção do Estado e um veículo de dominação de classe.

Tal situação coloca em risco a nova concepção de educação que tem emergido nos movimentos sociais do campo na medida em que sua essência, como afirma Souza (2007, p. 447), "se encontra na demanda de uma política pública orientada pelos próprios trabalhadores do campo". A forma de institucionalização das práticas educativas, como revelou nossa pesquisa, pode deslocar o centro de elaboração dessa política, tornando o Setor de Educação do MST de mediador das relaçóes sociais de luta do acampamento em mediador dos interesses do Estado.

\section{Notas}

1 Acreditamos ser oportuno acrescentar a reflexão de Casagrande (2002, p. 5): "desta forma, o MST diferencia-se historicamente de outros Movimentos campesinos, até o momento existentes, fundamentalmente pela importância que destaca à educação, colocando-a de igual para igual com a luta pela reforma agrária e as demais reivindicaçóes, bem como a considerando um dos pilares para a transformação social sendo vivida tanto nos espaços formais como a escola, quanto informalmente, na dinâmica das lutas que são travadas em seu cotidiano”.

2 Primeiro acampamento dos trabalhadores rurais, em 1980, no estado do Rio Grande do Sul. É considerado um marco no surgimento do MST. 
3 Tralha é como os sem-terra chamam seus pertences pessoais, como roupas e utensílios domésticos.

\section{REFERÊNCIAS}

BRASIL. Lei no 9.394, de 20 de dezembro de 1996. Estabelece as diretrizes e bases da educação nacional. Diário Oficial da União, Brasília, p. 27833, 23 dez. 1996. Disponível em: <https://www.planalto.gov.br/ ccivil_03/Leis/L9394.htm>. Acesso em: 10 dez. 2007.

CARTER, Miguel. O Movimento dos Trabalhadores Rurais Sem-Terra (MST) e a democracia no Brasil. Revista Agrária, São Paulo, n. 4, p. 124164, 2006.

CASAGRANDE, Nair. O processo de trabalho pedagógico no MST: contradições e superações no campo da cultura corporal. In: REUNIÃO ANUAL DA ASSOCIAÇÃO NACIONAL DE PÓS-GRADUAÇÃO E PESQUISA EM EDUCAÇÃO (Anped), 25., 2002, Caxambu. Anais eletrônicos... Caxambu, 2002. Disponível em: <http:/www.lpp-uerj.net/ olped/documentos/0006.pdf>. Acesso em: 10 dez. 2007.

CURY, R. J. Carlos. Educação e contradição: elementos metodológicos para uma teoria crítica do fenômeno educativo. São Paulo: Cortez; Autores associados, 2000.

DALMAGRO, Sandra L. O trabalho na pedagogia do MST. In: VENDRAMINI, Célia Regina (Org.). Educação em movimento na luta pela terra. Florianópolis: NUP/CED, 2002. p. 133-152.

FREIRE, Paulo. Pedagogia da esperança: um reencontro com a Pedagogia do Oprimido. 3. ed. Rio de Janeiro: Paz e Terra, 1999.

NASCIMENTO, Claudemiro Godoy do. Educação, lutas sociais e cidadania: práticas educativas da EFA em Goiás. In: REUNIÃO ANUAL DA ASSOCIAÇÃO NACIONAL DE PÓS-GRADUAÇÃO E PESQUISA EM EDUCAÇÃO (Anped), 28., 2005, Caxambu. Anais eletrônicos... Caxambu, 2005. Disponível em: <http://www.anped.org.br/ reunioes/28/textos/GT03/GT03-616--Int.rtf>. Acesso em: 10 dez. 2007.

SOUZA, Maria Antônia de. A pesquisa sobre educação e o Movimento dos Trabalhadores Rurais Sem Terra (MST) nos Programas de Pós- 
Graduação em Educação. Revista Brasileira de Educação, Rio de Janeiro, v. 12, n. 36, p. 443-461, set./dez. 2007.

VENDRAMINI, Célia Regina. Terra, trabalho e educação: experiências sócio-educativas em assentamentos do MST. Ijuí: UNIJUÍ, 2000.

WOOD, Ellen Meiksins. Democracia contra capitalismo: a renovação do materialismo histórico. São Paulo: Boitempo, 2003. . A origem do capitalismo. Rio de Janeiro: Zahar, 2001. 


\section{State, democracy and institutionalization of the social struggle in the educational practices of the MST: a case study of the itinerant school}

\section{Abstract}

This article analyzes the characteristics and contradictions of educational practices undertaken by the the Landless Workers Movement(MST), using itinerant schools as a reference. It particularly focuses on the problem of democracy and institutionalization of the social struggle, a central issue currently debated by social movements. The theoretical support for the study is based on historical and dialectical materialism and, particularly on the criticism made by Ellen Wood of representative democracy and limitations of the concept of "civil society". The research was carried out at two MST settlements in Rio Grande do Sul State, using semi-structured interviews, participative observation and document analysis. The results point out the institutionalization of the MST's educational practices, to attend to the formalities of government requirements., It found a trend towards bureaucratization and a distancing from the needs of the working class.

Keywords: Education and democracy. Education and class struggle. Social movements.

\section{Estado, democracia e institucionalización de las luchas sociales en las prácticas educativas del MST: un estudio de caso de la escuela itinerante}

\section{Resumen}

El principal objetivo de ese artículo es analizar las características y contradicciones de las prácticas educativas que se desarrollan en los campamentos del Movimiento de los Trabajadores Rurales Sin Tierra (MST), teniendo por referencia la Escuela Itinerante. Enfocamos especialmente el problema de la democracia y de la institucionalización de las luchas sociales, cuestión central con la cual se debaten los movimientos sociales en la actualidad. Basamos la investigación en el materialismo histórico y dialéctico $y$, nombradamente, en ese artículo, en la crítica de Eleen Wood a la democracia representativa y a las limitaciones del concepto de "sociedad civil". El estudio fue desarrollado en dos campamentos del MST localizados en Rio Grande do Sul, a través de encuestas semiestructuradas, observación participante y análisis de documentos. Los resultados obtenidos apuntan que la institucionalización de las prácticas educativas del movimiento, al atender las formalidades del Estado, tienden a la burocratización, alejándose de las necesidades de la clase trabajadora. Palabras clave: Educación y democracia. Educación y lucha de clases. Movimentos sociales. 


\section{Moacir Fernando Viegas}

E-mail:mviegas@unisc.br

Charles Luiz Policena Luciano

E-mail: charleslp2000@yahoo.com.br

Recebido em: 7/1/2010

Versáo final recebida em: $13 / 11 / 2010$

Aprovado em: 31/3/2011 